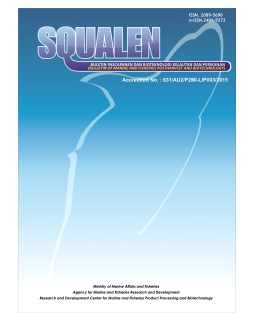

Squalen Bull. of Mar. \& Fish. Postharvest \& Biotech. 10 (3) 2015, 109-120

www.bbp4b.litbang.kkp.go.id/squalen-bulletin

Squalen Bulletin of Marine \& Fisheries Postharvest \& Biotechnology

ISSN: 2089-5690

e-ISSN: $2406-9272$

\title{
QUALITY CHANGES OF PANGASIUS FILLETS DURING ICE STORAGE
}

\author{
Diah Ikasari* and Theresia Dwi Suryaningrum \\ Research Center and Development Marine and Fisheries Product Processing and Biotechnology \\ Jalan KS. Tubun Petamburan VI, Slipi, Central Jakarta, Indonesia 10260 \\ Article history: \\ Received: 5 October 2015; Revised: 25 November 2015; Accepted: 28 November 2015
}

\begin{abstract}
Quality asessment of pangasius (Pangasius hypopthalmus) fillets stored in ice has been conducted. Fish were fasted for one day and slaughtered using bleeding techniques, drained for 10 minutes and filleted in various types of fillet: skin on, skinless, trimmed and untrimmed condition. Fillets were then washed and packed in vacuum plastics, stored in ice $\left(0-4{ }^{\circ} \mathrm{C}\right)$ for 18 days and observed for its sensory, chemical and microbiological parameters every 3 days. The sensory evaluation was conducted both for fresh or cooked fillets using scoring test on attribute of appearance, odor and texture as well as hedonic test. The chemical parameters observed were proximate; $\mathrm{pH}$ and Total Volatile Base (TVB); while microbiological parameter was Total Plate Count (TPC). Results showed that type of fillet did not significantly affect the quality of pangasius fillets. The quality of all treated fillet decreased in line with time of storage, all products were rejected after being stored for 18 days. At the time of rejection, the quality parameters: moisture content ranging from 80.1 to $81.3 \%$, TVB from 11.1 to $11.5 \mathrm{mg} \mathrm{N} / 100 \mathrm{~g}$ and TPC from 1.41 to $4.6 \times 10^{5} \mathrm{CFU} / \mathrm{ml}$. It is suggested to preserve pangasius fillets in ice less than 18 days.
\end{abstract}

Keywords: pangasius, fillets, quality, fat removal, skin removal

\section{Introduction}

Pangasius has become a promising fish commodity since it has high value both in domestic and global markets, easy to be cultivated and high resistant to pathogen (Ikasari \& Suryaningrum, 2014). The high demand of this species in the UE, USA, and UK has promoted Pangasius as aquaculture species in Indonesia (Polanco \& Luna, 2009). Recently, Pangasius industry have flourished in some regions in Indonesia, including Jambi, Riau and South Borneo. Production of Pangasius in Indonesia dramatically increased from 31.490 tons in 2006 to 651.000 tons in 2012 (Ditjen PEN, 2013). From 4 varieties of cultured Pangasius, namely Siam, Jambal, Nasutus and Pasupati (the hybrid of Siam and Jambal), Siam is higher number of production compared to other varieties (Anon., 2009a).

Pangasius is generally exported as fresh fish or in form of fillets. Fillets are preferred by consumers and has higher export value than fresh fish. Filleting is aimed to obtain the primary edible portion of fish, producing waste such as head, viscera, bones, fins, skin and adipose tissues. This process will result in only less than a half of fish weight or about $30-45 \%$ weight loss (38\% in average) (Morkore et al., 2001). Various ways have been done to increase the yield of fillets, such as filleting without removing the skin (skin on) nor fat (trimmed)(Sang et al., 2009; Sahu et al., 2013). According to Norwegian Industry Standard for Fish (1998), catfish fillets can be differentiated into four types depending on its various degrees of trimming and skinning. Type A, fillet is a whole fillet, without belly, bone and skin removal. Type B, fillet is a half fillet, with shoulder and sometimes stirrup bone removal as well as semi skinned (whole or part of the silver line is left on the fillet). Type $\mathrm{C}$, fillet is a trimmed fillet, with bones, thin belly as well as silver lining removal (normal skinning). Type $\mathrm{D}$, fillet is a boneless fillet, with all bone and belly removal as well as deep skinning, where the silver lining and parts of the brown muscle is removed from the fillet. For fresh fillet, type B, C, and D fillets are normally used. Nevertheless, types of fillet are considered to have an effect to the

${ }^{*}$ Corresponding author.

E-mail: diah_ika263@yahoo.com 
quality of fillets during storage, since some of the fillet forms still contain fat tissues (untrimmed fillet).

Appearance, texture, taste, chemical constituent and food safety are parameters that generally used to determine the quality of fish fillet (Robb, 2010). Some grades are used to differentiate fish fillet quality with the highest one is marked as Grade A. Fish fillet is regarded as grade $A$ when it represents good characteristic of the species, especially for flavour and odour as well as complying the limits of defects that is established by U.S Grade Determination (U.S Department of Commerce, 1979). The defects are including physical and chemical structure of fish flesh, colour and degree of surface dehydration of fillets, cutting and trimming imperfections, the present of bone and skin, and the texture of the cooked fillets. Nevertheless, all those parameters that determine the quality of fish fillets are influenced by primary processing of fish, including catching, slaughtering, bleeding, gutting, washing, and filleting (Border'ýas \& Isabel, 2010).

As one of the most highly perishable product, preventing the fish from deterioration process is important. Regarding to those issue, temperature is one of the factors with the strongest impact. Maintaining fish products at low temperature during storage is one of the best practices to prolong the shelf life (Giannakouroua et al., 2005). Chilling is the process of cooling fish or fish products to a temperature approaching that of melting ice, $0{ }^{\circ} \mathrm{C} / 32^{\circ} \mathrm{F}$ (Shawyer \& Pizzali, 2003). For fresh fillet products, the fish are usually packed in boxes and covered with polythene in ice (Norwegian Industry Standard for Fish, 1998). Chilling storage lowers the rate of deterioration.

Some studies regarding the quality deterioration of fish fillet during storage have been conducted. Riyanto et al. (2012) revealed that temperature and time of storage significantly affected the quality deterioration of Tilapia fish. Total Volatile Base Nitrogen (TVB-N) became the key parameter to determine the quality deterioration. Using Arhennius equation, Tilapia fish fillets with vacuumed packaging were predicted to have shelf life 6-7 days under chilling temperature (4-5 ${ }^{\circ}$ ) (Riyanto et al., 2012). Study conducted by Olafsdottir et al. (2006) which evaluated the influence of storage temperature on proliferation of specific spoilage organisms (SSO) and quality changes of haddock fillets, showed that microbial metabolites were produced in higher levels and shelf life was shorter with increasing storage temperature. Other study conducted by Ocaño-Higuera et al. (2009) indicated that the edible quality of cazon fish muscle, a cartilaginous fish that belongs to shark family, was maintained during at least 18 days of ice storage.
In terms of pangasius fillet, some studies has been focused on the addition of active compound to prolong its shelf life, including chitosan (Suptijah et al., 2008), red ginger and red galangal essential oil (Utami et al., 2013). Information regarding type of fillets form is also important to determine the effect of skin and fat removal during ice storage. Therefore, this study aimed to investigate the quality of various types of Pangasius fillets during ice storage.

\section{Material and Methods}

\subsection{Material}

The study used live pangasius (Pangasius hypopthalmus) obtained from Parung, Bogor, Indonesia measuring $500-700 \mathrm{~g}$ each; $39-45 \mathrm{~cm}$ total length; $32-37 \mathrm{~cm}$ body length; $6.2-8.1 \mathrm{~cm}$ body width; and $3.0-4.1 \mathrm{~cm}$ body thickness. The fish were divided into 4 groups (based on the treatments), each group contained 84 fish (covering 3 replications and 7 observation points). Other materials were ice blocks which were crushed and placed in a cool box to store the fish during the experiment.

\subsection{Methods}

\subsubsection{Preparation of pangasius fillets sample}

Fish were fasted for a day before slaughtered (Hastarini, 2007). The fish were then slaughtered by cutting directly the arteries part of fish head and then the blood was drained by hanging the fish upside down for 10 minutes (Ikasari \& Suryaningrum, 2014). Fish were filleted based on the treatments applied: SLU: skinless untrimmed, SOT: skin on trimmed, SLT: skinless trimmed, SOU: skin on untrimmed. All fillets being treated were boneless fillet. Each fillet was then vacuum packaged in High Density Poly Ethylene plastic (HDPE) (volume $500 \mathrm{ml}$ and 0.03 thickness) with $\pm 100-150 \mathrm{~g}$ of total weight for each packaging. Vacuum packaging was done using Single Chamber Vacuum Packaging Machine DZ 400/500 with absolute pressure of $1 \mathrm{kPa}$ and vacuum time of 25 second. The fillets stored within crushed ice layers in cool boxes with ratio of fish : ice $=1: 2$. The temperature inside the boxes was monitored using thermometer and maintained at $0-4{ }^{\circ} \mathrm{C}$ for 18 days (Ocaño-Higuera et al., 2009). The Pangasius fillet samples were observed for its quality every 3 days $(0,3,6,9,12,15,18$ days). The experiment was run in triplicates.

\subsubsection{Chemical analysis}

The chemical analysis was conducted for moisture content (AOAC, 2005), Total Volatile Base (TVB) 
using Conway method (AOAC, 2005) and $\mathrm{pH}$ value, which was measured for $10 \mathrm{~g}$ samples using digital $\mathrm{pH}$ meter. In addition, proximate composition, i.e ash content, protein content and fat content (AOAC, 2005) were observed at the beginning and end of experiment. The analysis was run in duplicates.

\subsubsection{Microbiology analysis}

For microbiology parameters, Total Plate Count (TPC) of pangasius fillet was determined by crushing $10 \mathrm{~g}$ pangasius fillet and aseptically dissolving (BSN, 2006) into $9 \mathrm{ml} \mathrm{Nacl} 0.85 \%$ sterile. Three serial dilutions were then grown on the petri dish using Plate Count Agar (PCA) and incubated at $37^{\circ} \mathrm{C}$ for 48 hours. The analysis was run in duplicates. The total microbe was stated in CFU/ml.

\subsubsection{Preparation of sensory sample}

The samples for sensory evaluation were prepared both as fresh and cooked samples. The cooked samples were prepared by wrapping each piece of fillet (100-150 $\mathrm{g}$ of total weight) with aluminium foil of $450 \mathrm{~mm}$ thickness and then steamed at $100{ }^{\circ} \mathrm{C}$ for 15 minutes.

\subsubsection{Sensory evaluation}

The fresh and cooked fillet samples were evaluated for their sensory attributes using scoring and hedonic tests conducted by 6 experienced panelists. The attributes measured for fresh fillet were appearance, texture, and odour; while attributes for cooked fillet were appearance, texture and taste (ASTM, 1968). The scoring test of fresh and cooked fillets were described with 1 to 5 scales, with 1 represents the lowest features and 5 represents the highest features. The lower scores mainly indicates there is quality decrease and score 1 is associated with the border line of each attribute (Table 1).

Hedonic test was done to investigate panelist preference to the pangasius fillet samples. The test is described with 1 to 7 scales, with 1 represents the most unpreferred attribute and 5 represents the most preferred attribute (Table 2).

\subsubsection{Data analysis}

The study was using Completely Randomized Design of experiment with two variables, namely type of fillet and time of storage. The obtained data were then statistically analysed by using PASW Statistics 18 programme. The analysis was carried out using ANOVA (One-way Analysis of Variance) at $5 \%$ level of significance $(p<0.05)$. A post-hoc test using Tukey's test was used for further analysis when a significant different was identified between samples.

Table 1. Scoring attribute scheme for fresh and cooked fillet of $P$. hypopthalmus

\begin{tabular}{|c|c|c|c|c|c|}
\hline \multirow{2}{*}{ Attribute } & \multicolumn{5}{|c|}{ Score } \\
\hline & 1 & 2 & 3 & 4 & 5 \\
\hline \multicolumn{6}{|l|}{ Fresh fillet } \\
\hline Appearance & $\begin{array}{l}\text { Brownish red } \\
\text { color, pale, } \\
\text { many } \\
\text { bloodstains }\end{array}$ & $\begin{array}{l}\text { Dominant reddish } \\
\text { color (uneven), } \\
\text { slightly pale, many } \\
\text { bloodstains }\end{array}$ & $\begin{array}{l}\text { Rosy beige color } \\
\text { (uneven), slightly } \\
\text { pale, few } \\
\text { bloodstains } \\
\text { (especially on } \\
\text { the tail) }\end{array}$ & $\begin{array}{l}\text { Yellow color, } \\
\text { bright, no } \\
\text { bloodstains }\end{array}$ & $\begin{array}{l}\text { Yellowish cream } \\
\text { color, bright, no } \\
\text { bloodstains }\end{array}$ \\
\hline Odor & $\begin{array}{l}\text { Pungent fishy } \\
\text { odor }\end{array}$ & Fishy odor & $\begin{array}{l}\text { Slightly fishy } \\
\text { odor }\end{array}$ & $\begin{array}{l}\text { Fresh, tend to } \\
\text { be neutral odor }\end{array}$ & $\begin{array}{l}\text { Fresh odor } \\
\text { (specific product) }\end{array}$ \\
\hline Texture & Very soft & $\begin{array}{l}\text { Not chewy, soft } \\
\text { and not compact } \\
\text { (rupture) }\end{array}$ & $\begin{array}{l}\text { Less chewy, } \\
\text { slightly mushy, } \\
\text { less compact }\end{array}$ & $\begin{array}{l}\text { Chewy, less } \\
\text { dense and } \\
\text { compact }\end{array}$ & $\begin{array}{l}\text { Chewy, dense } \\
\text { and compact }\end{array}$ \\
\hline \multicolumn{6}{|l|}{ Cooked fillet } \\
\hline Appearance & Dark yellow & Yellow & Cream & Whitish & White \\
\hline Texture & Very mushy & Mushy & Slightly mushy & $\begin{array}{l}\text { Less compact, } \\
\text { less dense }\end{array}$ & Compact, dense \\
\hline Taste & $\begin{array}{l}\text { Not good, taste } \\
\text { of mud }\end{array}$ & $\begin{array}{l}\text { Less tasty, bland, } \\
\text { a little taste of mud }\end{array}$ & $\begin{array}{l}\text { Tasty, slightly } \\
\text { savory }\end{array}$ & Tasty, savory & Very tasty \\
\hline
\end{tabular}


Table 2. Hedonic scheme for fresh and cooked pangasius fillet

\begin{tabular}{cl}
\hline Score & \multicolumn{1}{c}{ Meaning } \\
\hline 7 & Very like \\
6 & Like \\
5 & Slightly like \\
4 & Neutral \\
3 & Rather dislike \\
2 & Dislike \\
1 & Very dislike \\
\hline
\end{tabular}

\section{Results and Discussion}

\subsection{Moisture Content of Fillets}

There was no significant different for moisture content between time of storage $(P>0.05)$ (Figure 1). At day- 0 , moisture content of fillets were ranging from $78.9 \%$ to $80.0 \%$, and increased to $80.1-81.3 \%$ at day18. Skinless trimmed (SLT) fillet had a significantly higher moisture content compared to skin on untrimmed (SOU) fillet $(\mathrm{P}<0.05)$. Removing the skin from the fillet might cause larger surface area were exposed to the outside condition, allowing the fillet absorbed more water during washing process.

Moisture content is an important factor of food material because it affects sensory characteristics of the raw material as well as determines the growth of microorganisms. The higher moisture content of food materials, the faster the growth of microorganisms which leads to the quality decrease of the material (Afrianto \& Liviawaty, 1993).

\subsection{TVB}

TVB value shows the freshness of the fish fillets. TVB value is determined by molecular low weight volatile bases (TVB-N) which are produced by bacterial action, thus reflecting the level of deterioration process which is associated with quality of the flesh (OcañoHiguera et al., 2009).

Results of TVB values of pangasius fillet during storage was not significant $(P>0,05)$ (Figure 2). At day- 0 the TVB value were detected $10.58 \mathrm{mg} \mathrm{N} / 100 \mathrm{~g}$ and reached to $11.50 \mathrm{mg} \mathrm{N} / 100 \mathrm{~g}$ at day- 18 . However, the TVB values obtained in the study were still below the limit of acceptability (30-35 mg N/100g) (Ozyurt et al., 2009). The TVB values in this study were also much lower compared to previous study in pangasius fillet added with red ginger and red galangal essential oil $1 \%$ and stored at ice with TVB value of 33,5 $\mathrm{mgN} / 100 \mathrm{~g}$ (Utami et al., 2013). This probably caused by addition of ice during experiment. In order to maintain condition of storage staying at chilled

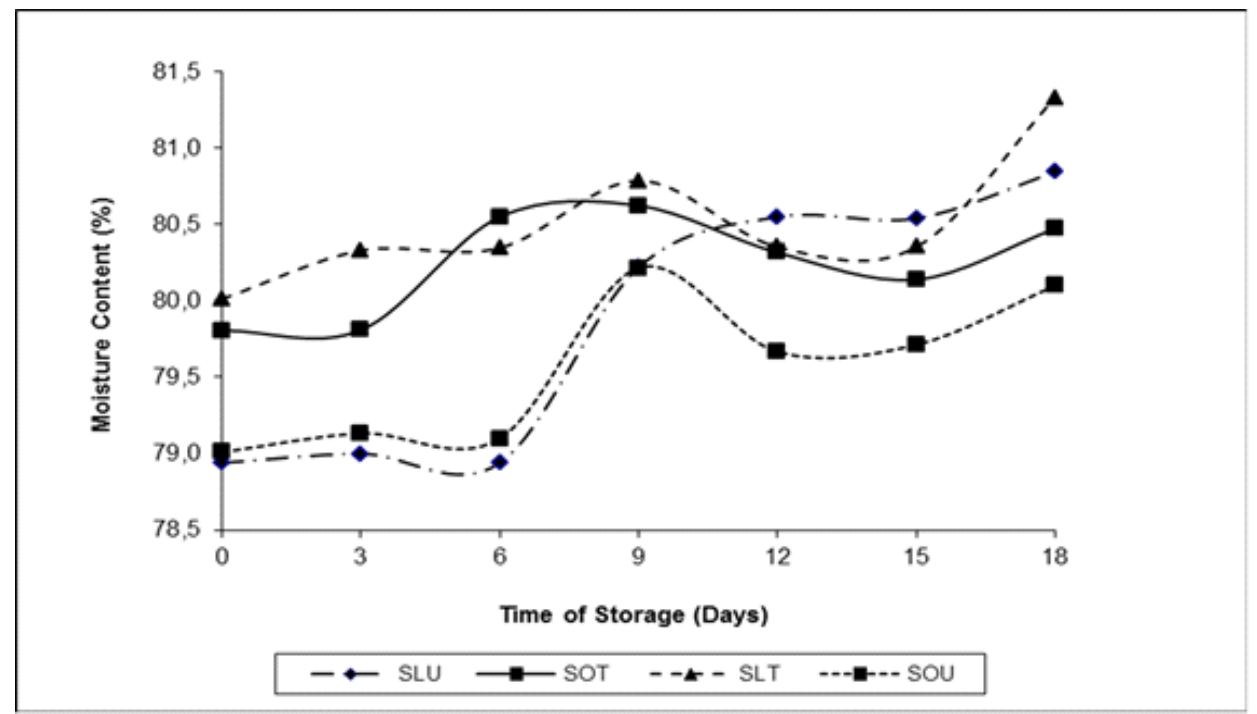

Notes: SLU: skinless untrimmed, SOT: skin on trimmed, SLT: skinless trimmed, SOU: skin on untrimmed

Figure 1. Moisture content of pangasius fillets during ice storage. 


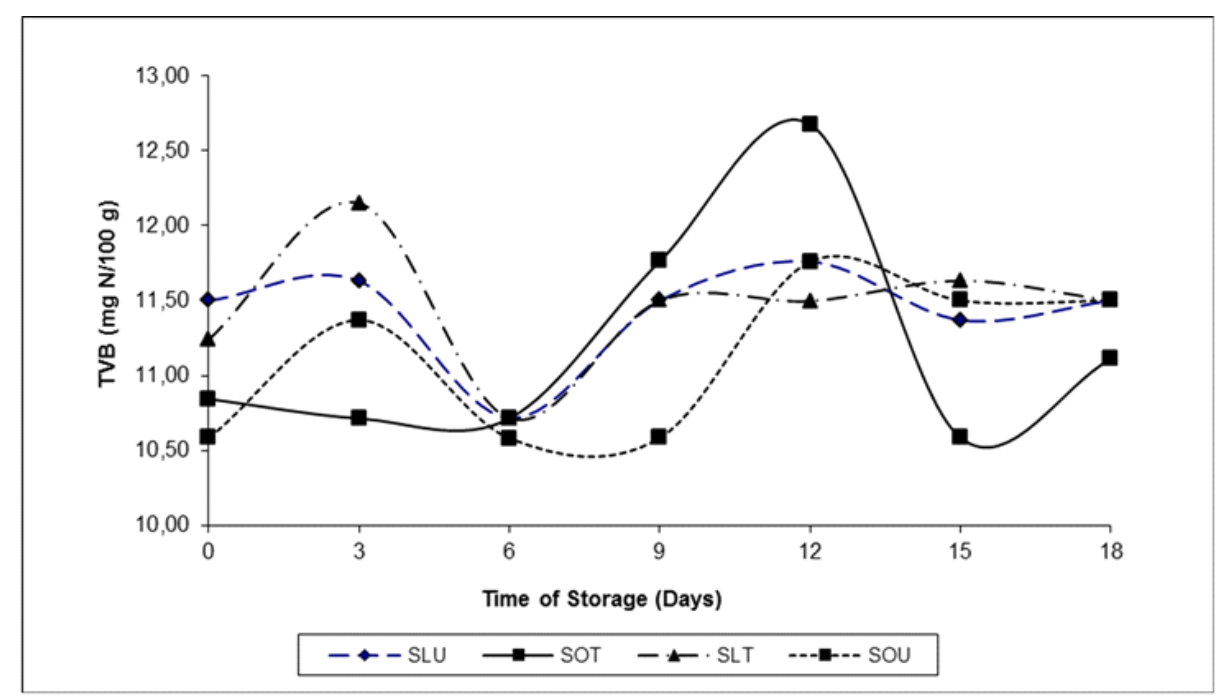

Notes: SLU: skinless untrimmed, SOT: skin on trimmed, SLT: skinless trimmed, SOU: skin on untrimmed

Figure 2. TVB value of pangasius fillets during ice storage.

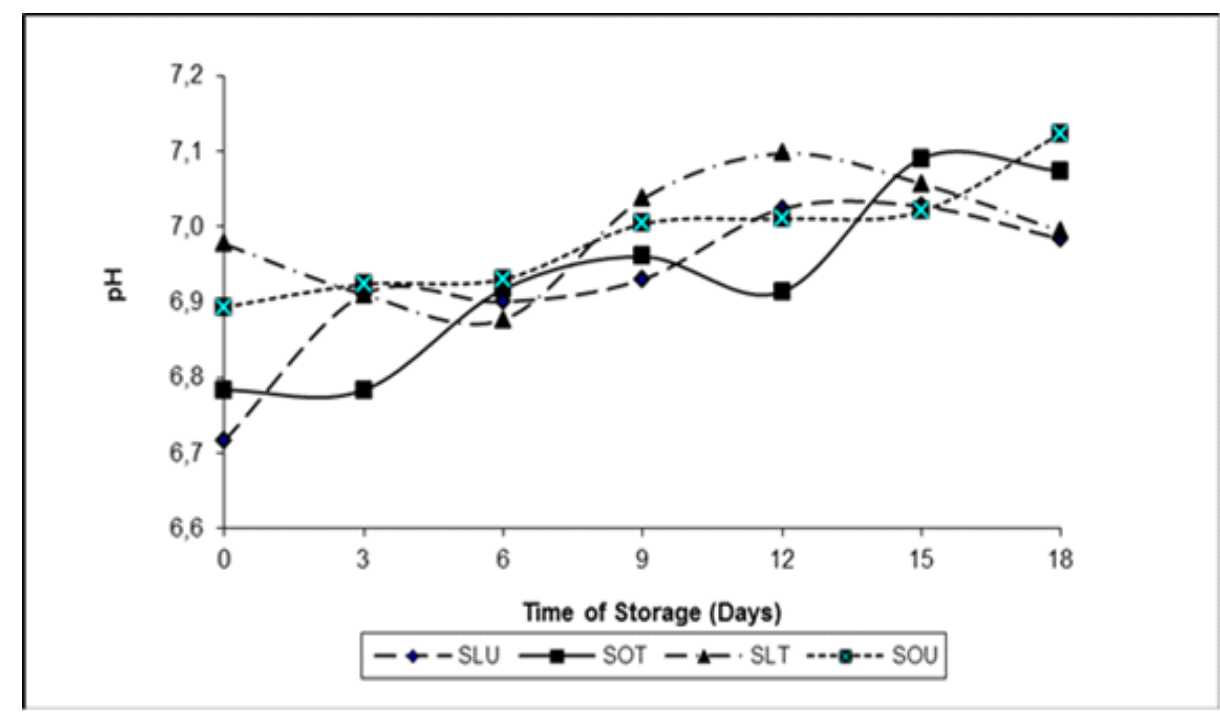

Notes: SLU: skinless untrimmed, SOT: skin on trimmed, SLT: skinless trimmed, SOU: skin on untrimmed Figure 3. $\mathrm{pH}$ of pangasius fillets during ice storage.

temperature $(0-4 \stackrel{\circ}{\circ})$ during experiment, some amount of crushed ice were added to the boxes. This process caused washing effect to the fillet, so that the TVB value remained almost constant in the fillet. At the end of experiment (day-18), the fillets were categorized still in fresh condition. There was no significant difference between treatments and time of storage on the TVB values of pangasius fillets $(P>0.05)$.

\section{3. $\mathrm{pH}$}

Results of $\mathrm{pH}$ analysis of pangasius fillet showed that $\mathrm{pH}$ increased as the time of storage $(\mathrm{P}<0.05)$ (Figure 3).
The $\mathrm{pH}$ values of pangasius fillets tended to increase during the ice storage, ranging from 6.84 to 7.04 (Figure 3). According to Poli et al. (2005), pH of fresh fish is around 6.5. Storage time tends to increase the $\mathrm{pH}$ values which can be associated with the production of basic components such as ammonia, volatile alkali and trimetilamin due to internal enzymatic activity and the growth of bacteria (Simeonidou et al., 1998; Arannilewa et al., 2005; Chamarana et al., 2012). In this study, TVB value might not showing correlation with $\mathrm{pH}$ due to washing effect of ice (Figure 2), but the increase of total bacteria count during storage (Table 3) indicated that there was a correlation between 
Table 3. Total bacteria count of pangasius fillets during 18 days ice storage.

\begin{tabular}{lccccccc}
\hline & \multicolumn{7}{c}{ Total Plate Count (cfu/ml) } \\
\cline { 2 - 8 } & $\mathbf{0 ~ d}$ & $\mathbf{3} \mathbf{d}$ & $\mathbf{6} \mathbf{d}$ & $\mathbf{9} \mathbf{d}$ & $\mathbf{1 2} \mathbf{d}$ & $\mathbf{1 5} \mathbf{d}$ & $\mathbf{1 8} \mathbf{d}$ \\
\hline SLU & $2.10 \times 10^{3}$ & $6.50 \times 10^{3}$ & $6.65 \times 10^{3}$ & $1.85 \times 10^{4}$ & $2.50 \times 10^{4}$ & $2.53 \times 10^{4}$ & $1.41 \times 10^{5}$ \\
SOT & $1.90 \times 10^{3}$ & $8.30 \times 10^{3}$ & $1.63 \times 10^{4}$ & $3.20 \times 10^{4}$ & $1.50 \times 10^{4}$ & $2.13 \times 10^{5}$ & $4.36 \times 10^{5}$ \\
SLT & $1.65 \times 10^{3}$ & $4.55 \times 10^{3}$ & $1.08 \times 10^{4}$ & $2.24 \times 10^{4}$ & $2.50 \times 10^{4}$ & $2.80 \times 10^{4}$ & $3.30 \times 10^{5}$ \\
SOU & $1.46 \times 10^{3}$ & $3.05 \times 10^{3}$ & $4.56 \times 10^{3}$ & $7.10 \times 10^{3}$ & $1.15 \times 10^{4}$ & $3.56 \times 10^{4}$ & $4.60 \times 10^{5}$
\end{tabular}

Notes: SLU: skinless untrimmed, SOT: skin on trimmed, SLT: skinless trimmed, SOU: skin on untrimmed

$\mathrm{pH}$ and the growth of bacteria. The increase of total bacteria count showed in accordance with the increase of $\mathrm{pH}$ during experiment. However, the increase of the $\mathrm{pH}$ was not significant $(\mathrm{P}<0.05)$ since the temperature was maintained at $0-4 \stackrel{\circ}{\circ}$ and only certain bacteria could grow at these condition.

In addition, there was no significant difference found between type of pangasius fillet $(P>0.05)$. Treatments of skin and fat removal did not affect significantly to the $\mathrm{pH}$ of pangasius fillets.

\subsection{Ash, Fat and Protein Content of Fillets}

Analyses of proximate composition of pangasius fillets at the beginning and end of experiment were conducted to demonstrate the changes of proximate value of pangasius fillets before and after 18-days storage at chilled temperature.

Figure 4 showed that fat content at day- 0 and day18 of experiment. Fat content of pangasius fillets at the beginning and end of experiment showed significantly different between treatments $(P<0.05)$. For fillets SLU and SOT, fat content was detected to decrease, from 1.51 and 1.37 to 1.34 and 1.20 respectively. Meanwhile for fillets SLT and SOU, fat content slightly increased from 1.45 and 1.77 to 2.58 and 2,91 respectively. In addition, ash and protein content of pangasius fillets tended to decrease at day18 in all treatments. A sharp decrease occurred in fillets SLT and SOU from $1.27 \%$ and $1.28 \%$ to 1.15 and $0.96 \%$ for ash content and from 17.20 and 17.12 to 15.60 and 15.46 for protein content, respectively. However, according to statistic data, both the increase of fat content and the decrease of ash as well as protein content were insignificantly different $(P>0.05)$. This fact indicates that there was no correlation between proximate value and quality deterioration of pangasius fillets. The proximate value remained constant although the fillets indicates quality deterioration during storage.

\subsection{Microbiological Parameters}

The total bacteria count (TPC) of pangasius fillets increased with the time of storage (Table 3 ). The total bacteria count at day-0 were ranging from 1.46 to $2.1 \times 10^{3} \mathrm{cfu} / \mathrm{ml}$. These numbers increased to $10^{5} \mathrm{cfu} / \mathrm{ml}$ after 18 days of storage in all treatments. The results indicate that deterioration process was occurred during ice storage of the pangasius fillets. Bacteria play an important role in the deterioration process since it can degrade the organic matter. Until day-15 the number of total bacteria was still in range of the standard established by Indonesian National Standard Agency (BSN) (2006) fisheries products, which is below $10^{5}$. Total bacteria number was at the limit of the standard at day-18 where the TPC value ranging from 1.41 to $4.6 \times 10^{5} \mathrm{cfu} / \mathrm{ml}$.

Deterioration of fish normally influenced by several factors, including the species, the physiological condition of fish, microbial contamination and temperature. Temperature is observed to be strongest impact, because it can control the endogenous enzymes present in the muscle as well as the growth of bacteria. Therefore, decreasing temperature as quick as possible during handling and storage is important to preserve fresh freshness and quality (Ocano-Higuera et al. , 2006). Under ice storage, the shelf life of aquacultured meagre (Argyrosomus regius) fillet was reported only 9 days (Hernández et al., 2009). Nevertheless, the result of this study indicated longer shelf life with 18 days of ice storage. According to Johnston et al. (1994), the recommended storage temperature for all fishery products is $-30 \stackrel{\circ}{ } \mathrm{C}$ where spoilage by bacterial action in any practical sense is completely arrested at this temperature and the rate of other undesirable changes is greatly reduced.

Moreover, skin on fillets seemed to have higher total microbial compared to skinless fillet, so as untrimmed fillet compared to trimmed fillet. At day- 18 SOU showed the highest total microbes with $4.6 \times 10^{5}$ 




Notes: SLU: skinless untrimmed, SOT: skin on trimmed, SLT: skinless trimmed, SOU: skin on untrimmed

Figure 4. Ash (A), protein $(B)$ and fat $(C)$ content of pangasius fillets during ice storage.

$\mathrm{cfu} / \mathrm{ml}$. The presence of skin was believed to be one of contamination source as stated by Fernandes (2009) that the surface of fresh flesh fish considered as sterile while skin, gills and gastrointestinal tract are contained microorganism colonies.

\subsection{Scoring Test of Fresh and Cooked Fillets}

Results of scoring test of fresh fillet showed that longer storage contributed to the decrease of pangasius fillet's appearance (Figure 5A). At day-18, the score was significantly different from day- $0,3,6$, 9,12 and $15(P<0.05)$. The scores were ranging from 3,83 to 4,50 at day-0 and dropped to $2,17-3$ at day18 , which describes that the fillets were dominantly spotted with red color and the flesh seemed to be pale. However, there is no significant difference between treatments in terms of fillet's type for skin on and skinless as well as trimmed and untrimmed $(P>0.05)$.
Similar trends were also showed by scoring test result for attribute of odor and texture (Figure 5B and $5 \mathrm{C})$. Panelist tended to give lower score for fillet with longer storage (18-days storage). The scores given at day-0 were 4,50-4,56 and 4,44-4,78 for odor and texture respectively. At day-18, the score decreased significantly $(P<0.05)$ to $3,00-3,22$ and 2,17-2,44 for odor and texture respectively. The odor of the fillets tended to decrease from fresh to neutral (no odor) and the texture of the fillet were less springy. However, treatment of removing the fish skin and fat seemed did not give any significant effect to the attribute of odor and texture of pangasius fillets $(P>0.05)$.

In accordance to the result of fresh fillet scoring test, the results of cooked fillets scoring test for attributes appearance, texture and taste showed similar trend between treatments (Figure 6). According to panelist, 18 days of storage gave a significant difference to the attribute of appearance, texture and taste $(P<0.05)$. At day-0 the scores were 4.33-4.50; 


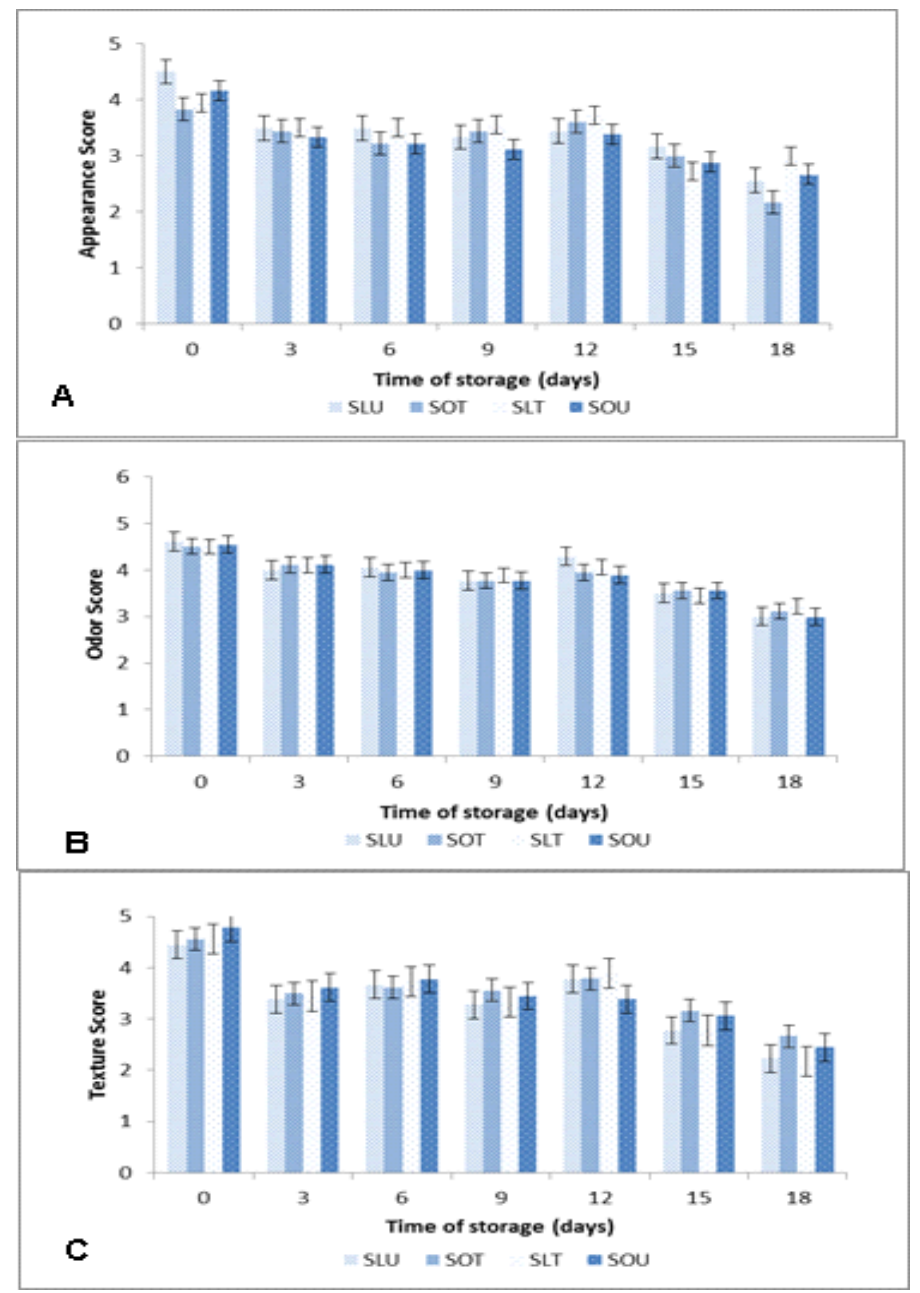

Notes: SLU: skinless untrimmed, SOT: skin on trimmed, SLT: skinless trimmed,

SOU: skin on untrimmed "Different alphabet means significantly different

Figure 5. Scoring test for attribute of appearance (A), odor (B) and texture (C) of fresh pangasius fillets during ice storage.

4.50-4.61; 4.89-4.00 and dropped to $2.83-3,17 ; 2.33-$ $2.67 ; 2.17-2.44$ for appearance, texture and taste respectively. Panelist considered that fillets with longer storage had changed its color from whitish to yellowish; the texture tended to mushy and the taste was bland with slightly muddy sense.

Moreover, based on statistic data, it is shown that there was also a significant difference between treatments for attributes of texture and taste $(P<0.05)$. Fat removal resulted fillet with more compact texture, while skin removal produced less good taste. This result is in accordance with previous study which reported that sensory quality of fish fillets was indicated by textural properties and flavors more than appearances and colors (Phan \& Nguyen, 2012). Fat was reported to affect the texture properties. Study conducted by Andersen et al. (1997) revealed that fish contains high fat indicating a softer consistency and less tough texture during 11 days ice storage due to higher autolytic protease activity. Fat tissue is also found in the layer just beneath the fish skin, so that when the fillet cooked with the skin-on, the skin soaks up these fats, relieving good taste and flavour.

\subsection{Hedonic Test of Fresh and Cooked Fillets}

Results of hedonic test both for fresh and cooked Pangasius fillets during storage showed a significant decrease as the time of storage $(P<0.05)$ (Figure 7). At day-0 panelists gave score 5.56-6.11 and 5.89-6.28 for fresh and cooked fillets respectively, which means that they slightly like to like the product. A sharp decrease had been shown at day-15 and day-18, means that the fillets with longer storage were disliked by panelists. The score given at day-18 were 3.393.67 and 3.33-4.00 for fresh and cooked fillets respectively, which means panelists rather dislike to 


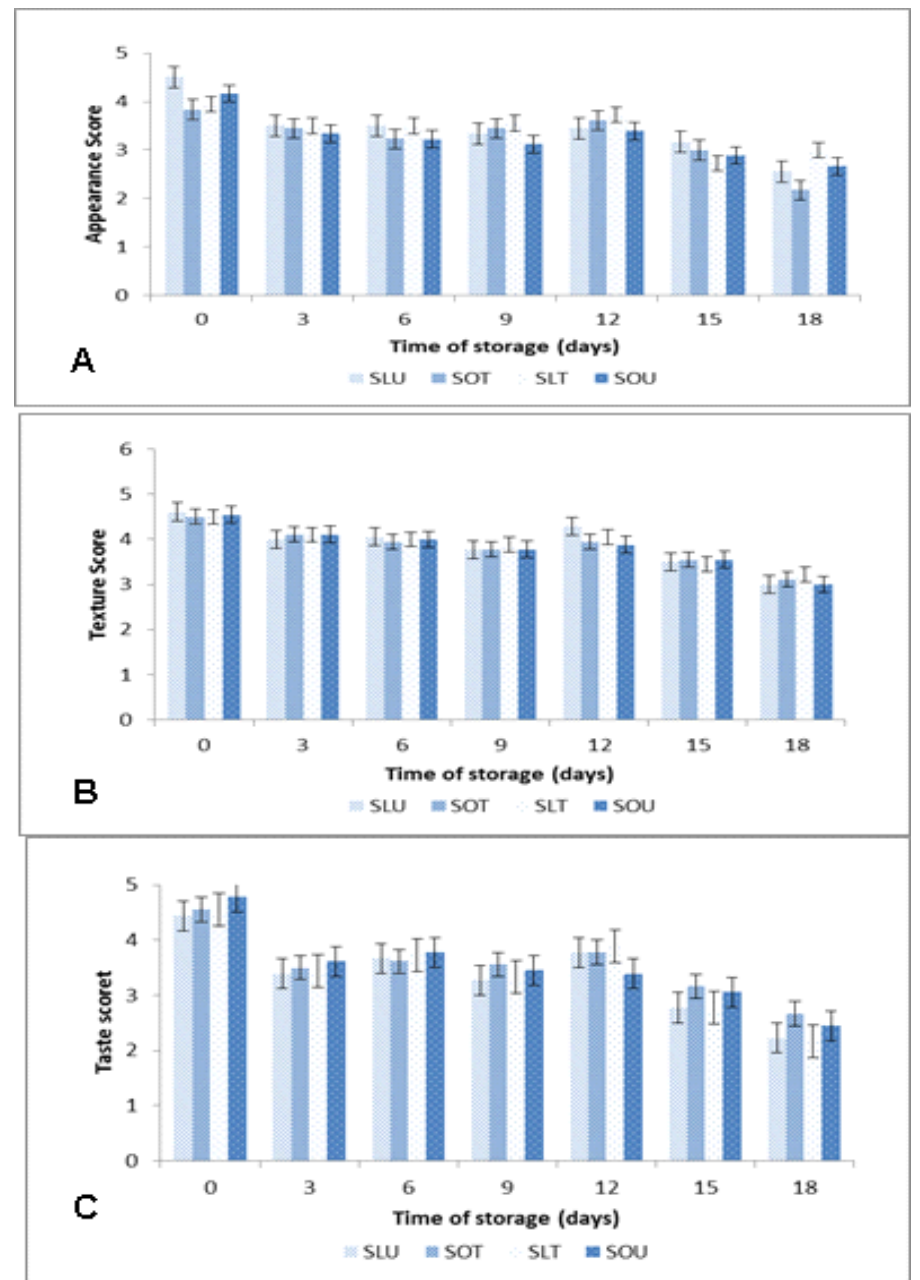

Notes: SLU : skinless untrimmed, SOT : skin on trimmed, SLT : skinless trimmed, SOU: skin on untrimmed "Different alphabet means significantly different

Figure 6. Scoring test for attribute of appearance (A), odor (B) and texture $(C)$ of cooked pangasius fillets during ice storage.

neutral or did not have any preferences. These results were in line with the results of scoring test, where a significant change occurred at day-15 and day-18 for attribute of appearance, odor and texture of pangasius fillets.

According to statistic data, there was a significant difference between fillets with and without skin removal as well as with and without fat removal, especially for cooked fillets $(P<0.05)$. Skin on trimmed fillet obtained higher score compared to other treatments with 4,00 at day-18. Panelist preferred fillets without skin removal but with fat removal compared to others. This result is surprisingly different with typical specification of pangasius fillet product that is preferred in the market, which is mostly in skinless form.

There are various shapes of pangasius fillet available in the market. They are generally distinguished by the presence of skin and fat. Fillet product without skin removal usually has specification of skin on, boneless, red meat on, belly on and fat on. Meanwhile, fillet product with skin removal is available in 3 categories, namely well-trimmed, untrimmed and semi-trimmed. The well-trimmed fillet is specified by skinless, boneless, red meat-off, belly-off and fat-off. The untrimmed fillet is characterized by skinless, boneless, red meat on, belly on and fat on. The semitrimmed fillet has slightly different with untrimmed fillet, characterized by skinless, boneless, red meat on, belly on and fat on but the amount of red-meat, belly and fat are far less compared to untrimmed fillet (Anvifish, 2015). The most popular form of pangasius fillet is boneless, skinless or portions in different sizes and shapes cut from fillets. Fillets can range in size up to 6-8 ounces (National Marine Fisheries Service, 2011). 

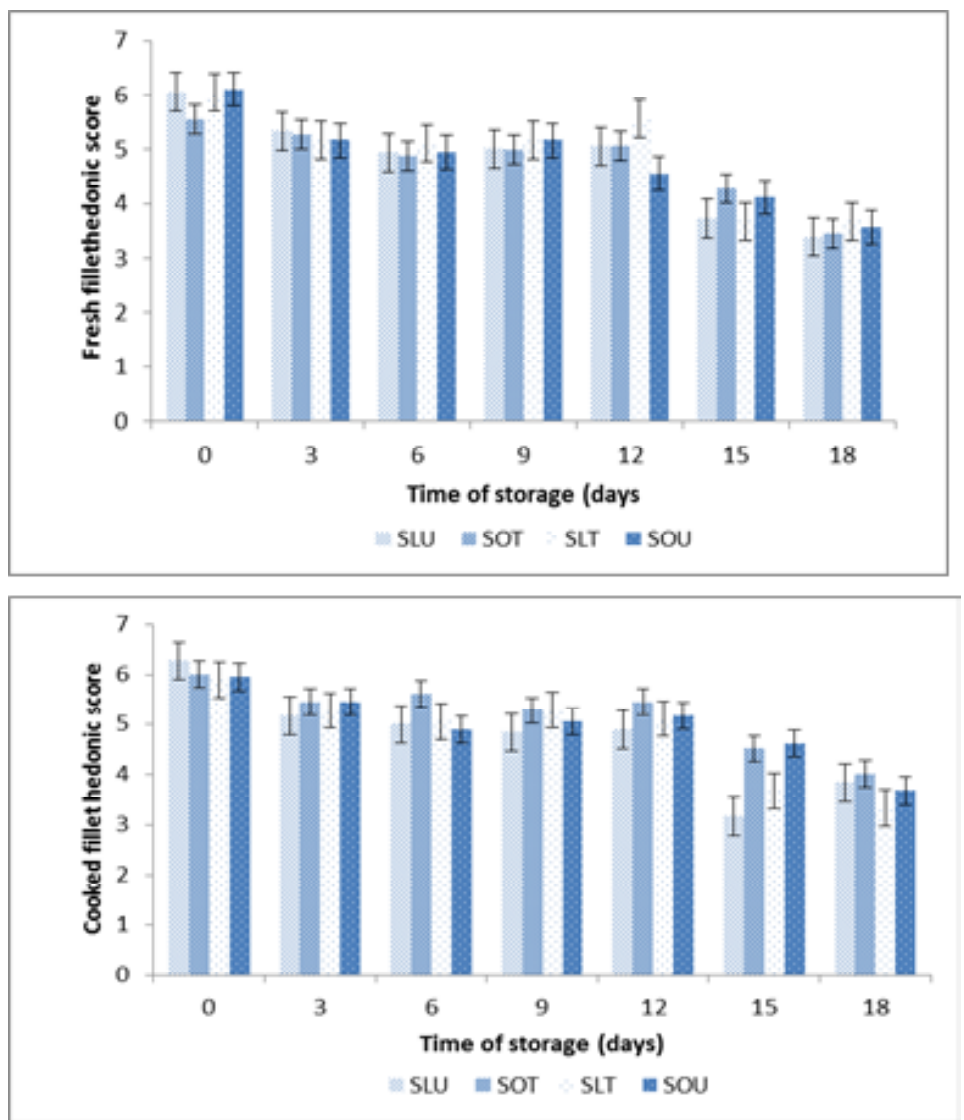

Notes: SLU : skinless untrimmed, SOT : skin on trimmed, SLT : skinless trimmed, SOU: skin on untrimmed "Different alphabet means significantly different

Figure 7. Hedonic test of fresh (A) and cooked (B) pangasius fillets during ice storage.

Based on the results of chemical and microbiology analysis as well as sensory evaluation, type of fillet did not affect significantly to the quality of pangasius fillets. The quality decrease of pangasius fillets can be detected during 18 days ice storage. Until day-18, the chemical and microbiology analysis results showed that the quality of pangasius fillets was still below the standard. However, sensory evaluation showed that the fillets were acceptable only by day15 and then rejected at day-18 of storage due to parameter decrease indications such as yellowish colour, off-odor and mushy texture. This result leads to conclusion that pangasius fillets are suggested to be preserved in ice storage less than 18 days.

\section{Conclusion}

Treatment of skin and fat removal did not significantly influence the quality of pangasius fish fillets during 18-day ice storage. The quality of all treated fillets decreased in line with time of storage, all product was rejected after being stored for 18 days. At the time of rejection, the quality parameters: moisture content ranging from 80.1 to $81.3 \%$, TVB from 11.1 to $11.5 \mathrm{mg} \mathrm{N} / 100 \mathrm{~g}$ and TPC from 1.41 to $4.6 \times 10^{5} \mathrm{cfu} / \mathrm{ml}$. It is suggesed to preserve pangasius fillets in ice less than 18 days.

\section{References}

Afrianto, E \& Liviawaty, E. (1993). Fish Preservation and Processing. Kanisius. Yogyakarta

AOAC. (2005). Official Methods of Analysis of The Association of Official Analytical Chemist. Inc. Washington. DC.

Andersen, U.B., Thomassen, M.S \& Bencze, A.M (1997). Texture Properties of Farmed Rainbow Trout (Oncorhynchus mykiss): Effects of Diet, Muscle Fat Content and Time of Storage on Ice. Journal of the Science of Food and Agriculture, 74(3): 347-353.

Anonymous. (2009). Pangasius hypopthalmus, The Controversial Fish. Warta Perikanan. Oktober Edition, 74: $18-19$.

Anvifish. (2015). Frozen Pangasius Fillet. Retrieved on $08^{\text {th }}$ October 2015 from http://www.anvifish.com/en/ products.

Arannilewa, S. T, Salawu, S. O, Sorungbe, A. A \& OlaSalawu, B. B. (2005). Effect of frozen period on the chemical, microbiological and sensory quality of 
frozen tilapia fish (Sarotherodun galiaenus). African Journal of Biotechnology, 4(8): 852-855.

ASTM (American Society for Testing and Materials). (1968). Manual on Sensory Testing Methods. ASTM, Philadelphia. 78pp.

Border'ýas, A. J \& Isabel, S. (2010). First processing steps and the quality of wild and farmed fish. Journal of Food Science, 76(1): R1-R5. Retrieved on December $15^{\text {th }} 2014$ from http://online library. wiley. com/doi/10.1111/j.1750-38 41. 20 10.01900.x/pdf.

BSN (Indonesian National Standard Beureu). (2006). Microbiological Testing Part 3: Total Plate Count determination for fisheries products. SNI 01-2332.32006.

Boulares, M., Mejri, L. \& Hassouna, M. (2011). Study of the microbial ecology of wild and aquacultured Tunisian fresh fish. Journal of Food Protection, 74(10):1762-1768.

Chamanara, V., Shabanpour, B., Gorgin, S. and Khomeiri, M. (2012). An investigation on characteristics of rainbow trout coated using chitosan assisted with thyme essential oil. International Journal of Biological Macromolecules, 50: 540-544.

Ditjen PEN. (2013). Indigenous Pangasius Hypopthalmus fish has economical value and potency for high export commodity. Retrieved on March $5^{\text {th }} 2014$ from http://djpen.kemendag.go.id/ app_frontend/webroot/admin/docs/publication/ 8241384233598.pdf.

Fernandez Polanco, J., \& Luna, L. (2009). The Pangasius market in Spain. Aqua Culture Asia Pacific. Retrieved from http://www.aquaasiapac.com.

Fernandes, R. (2009). Microbiology Handbook Fish and Seafood. Leatherhead Publishing. Leatherhead Food International Ltd., Cambridge, UK. p 3.

Giannakouroua, M., Koutsoumanisb, K., Nychasc, G., \& Taoukis, P. (2005). Field evaluation of the application of time temperature integrators for monitoring fish quality in the chill chain. International Journal of Food Microbiology, 102, 323-336

Hastarini, E., Lestari, D.A. (2007). Research on the Development of Surimi based Products. Technical Report. Research and Development Center for Marine and Fisheries Product Processing and Biotechnology. Jakarta

Hernández, M.D,, López, M.B., Álvarez, A., Ferrandini, E., García García, B. \& Garrido, M.D.(2009). Sensory, physical, chemical and microbiological changes in aquacultured meagre (Argyrosomus regius) fillets during ice storage. Food Chemistry, 114: 237-245.

Ikasari, D \& Suryaningrum, T. D. (2014). Effect of slaughtering techniques on the quality of fresh "Pangasius Hypopthalmus Hypopthalmus" fish (Pangasius sp.) stored at ambient temperature. Squalen : Bulletin of Marine and Fisheries Postharvest and Biotechnology, 9(2): 63-74.

Johnston, W.A.,Nicholson, F.J., Roger, A., \& Stroud, G. D. (1994). Freezing and refrigerated storage in fisheries. FAO Fisheries Technical paper. Retrieved on January $5^{\text {th }} 2016$ from http://www.fao.org/docrep/003/v3630e/ V3630E08.htm.
Morkore, T., Vallet. J.L., Cardinal, M., Montero, R., Torrissen, O. J.,Nortvedt, R., Sigurgisladottir, S., \& Thomassen, M. S. (2001). Fat content and fillet shape of Atlantic salmon: Relevance for processing yield and quality of raw and smoked products. J. Food Sci. 66, 1348-1354.

National Marine Fisheries Service, (2011). Pangasius. Retrieved on $8^{\text {th }}$ October 2015 from http://seafood healthfacts.org/seafood_choices/pangasius.php.

Norwegian Industry Standard for Fish. (1998). Whitefish fillets and fillet products. Industry Standard No NBS 40-02, Bergen, Norway.

Ocano-Higuera, V. M., Maeda-Martínez, A. N., LugoSánchez, M. E., \& Pacheco- Aguilar, R. (2006). Postmortem biochemical and textural changes in the adductor muscle of catarina scallop stored at $0^{\circ} \mathrm{C}$. Journal of Food Biochemistry, 30(4), 373-389.

Ocaño-Higuera, V. M., Marquez-Ríos, E., CanizalesDávila, M., Castillo-Yáñez, F. J., Pacheco-Aguilar, R., Lugo-Sánchez, M. E., \& Graciano-Verdugo, A. Z. (2009). Postmortem changes in cazon fish muscle stored on ice. Food Chemistry, 116(4), 933-938. http:/ /doi.org/10.1016/j.foodchem.2009.03.049.

Ojagh, S.M., Rezaei, M., Razavi, S.H. \& Hosseini, S.M.H. (2010). Effect of chitosan coatings enriched with cinnamon oil on the quality of refrigerated rainbow trout. Food Chemistry 120: 193-198.

Olafsdottir, G., Lauzon, H., Martinsdottir, E., \& Kristbergsson, K. (2006). Influence of storage temperature on microbial spoilage characteristics of haddock fillets (Melanogrammus aeglefinus) evaluated by multivariate quality prediction. International Journal of Food Microbiology, 111(2), 113-125.

Ozyurt, G., Kuley, E., Ozkutuk, S. \& Ozogul, f. (2009). Sensory, microbiological and chemical assessment of the freshness of red mullet (Mullus barbatus) and goldband goatfish (Upeneus moluccensis) during storage in ice. Food Chemistry, 114: 505-510.

Phan, U. T. X., \& Nguyen, D. H. (2012). Flavor of cooked fish (Pangasius hypophthalmus) fillets as prediction from raw fresh and frozen-to-thawed. Journal of Sensory Studies, 27(1), 12-25. http://doi.org/10.1111/ j.1745-459X.2011.00363.x.

Poli, B. M., Parisi, G., Scappini, F. \& Zampacavallo, G. (2005) Fish welfare and quality as affected by preslaughter and slaughter management. Aquaculture International 13, 29-49.

Riyanto, R.; Supriyadi; Suparmo \& Heruwati, E. S. (2012). Shelf life prediction equation of Tilapia's (Oreochromis niloticus) fillet vacuum packed in HDPE. Jurnal Pascapanen dan Bioteknologi, 7(2): 105-116.

Robb, D. (2010). Factors affecting fish quality: focus on farmed salmon. EWOS Innovation. Retrieved on March $5^{\text {th }} 2014$ from http://praise.manoa.hawaii.edu/ content/aip/Factors Affecting Fish Quality Focuson FarmedSalmon.pdf.

Sahu, B.B., Sahoo, S.K., Giri, S.S., Das, P.C., Mishra, B., Sahu, A.K., Jayasankar, P. (2013). Carcass traits of two marketable size classes of Pangasius Pangasius (Hamilton, 1822). Journal of Applied Ichthyology, 
29(1), 226-229. http://doi.org/10.1111/j.14390426.2012.02059.x.

Sang, N. Van, Thomassen, M., Klemetsdal, G., \& Gjøen, H. M. (2009). Prediction of fillet weight, fillet yield, and fillet fat for live river fish (Pangasianodon hypophthalmus). Aquaculture, 288(3-4), 166-171. http://doi.org/10.1016/j.aquaculture.2008.11.030.

Shawyer, M., \& Pizzali, A. F. (2003). The use of ice on small fishing vessels. Rome: FAO.Sigholt, T., Erikson, U., Rustad, T., Jouhansen, S., Nordtved, T., \& Seland, A. (1997). Handling stress and storage semperature affect meat quality of farmed-raised Atlantic Salmon (Salmo Salar). Journal of Food Science, 62(4), 898905.

Suptijah, P., Gushagia, Y., \& Sukarsa, D. R. (2008). Study of inhibitory effects of chitosan on quality deterioration of Catfish (Pangasius hypopthalmus) fillet at room temperature storage. Buletin Teknologi Hasil Perikanan, 6(2): 89-101.

Simeonidou, S., Govans, A.,\& Vareltzis, K. (1998). Quality assessment of seven Mediterranean fish species during storage on ice. Food Res.Int., 30: 479-484.

U.S. Department of Commerce. (1979). U.S.general standards for fish fillets. Fed. Regist. 44(110):3238532388. Retrieved on December $15^{\text {th }} 2014$ from http:/ www.seafood.nmfs.noaa.gov/pdfs/generalfillets.pdf.

Utami, R., Kawiji, Nurhartadi, E., Kurniasih, M., \& Indianto, D. (2013). Effect of edible coating enriched with red ginger and red galangal essential oil on the quality of patin fillet. Agritech, 33(4): 399-406.

Wardle, C. (1997). Welfare of Farmed Salmon and impact on Post Harvest Quality. In: Welfare of Fish at Slaughter. Ed. D. Robb. University of Bristol, United Kingdom, pp 25-30. 